\title{
When is earnings management really good news? Evidences from Indonesia
}

\section{Felizia Arni Rudiawarni*, Dedhy Sulistiawan and Yie Ke Feliana}

\author{
Accounting Department, \\ University of Surabaya, \\ J1. Raya Kalirungkut, Surabaya 60293, \\ East Java, Indonesia \\ Email: felizia@staff.ubaya.ac.id \\ Email: dedhy@ubaya.ac.id \\ Email: yiekefeliana@staff.ubaya.ac.id \\ *Corresponding author
}

\begin{abstract}
This study aims to examine the impact of earnings management and stock return. The magnitude of accruals and operating cash flows are the important feature that we add to this study. This feature gives deeper analysis of how earnings management affects stock return. We use Indonesian data from 2011 to 2013 as our sample. Three earnings management models are applied for this research: (1) Jones, (2) Modified Jones and (3) Kaznik model. We find that discretionary accruals cannot explain stock return, but after considering the magnitude of accruals and operating cash flow the result is different. Discretionary accruals affect stock return positively, only when accruals are higher than operating cash flow. These findings contribute to earnings management and market-based accounting researches.
\end{abstract}

Keywords: earnings management; accruals; return.

Reference to this paper should be made as follows: Rudiawarni, F.A., Sulistiawan, D. and Feliana, Y.K. (2017) 'When is earnings management really good news? Evidences from Indonesia', Int. J. Trade and Global Markets, Vol. 10, No. 1, pp.47-57.

Biographical notes: Felizia Arni Rudiawarni is a Lecturer at Accounting Department University of Surabaya. She received master degrees in Accounting from University of Surabaya and now she is a doctoral student in accounting at Airlangga University. She is interested in financial accounting, especially in earnings management. She also published articles in several international journals.

Dedhy Sulistiawan is a Lecturer at Accounting Department University of Surabaya. He received Doctoral degree in Accounting from Gajah Mada University. His research interest is market-based-accounting research and behavioural accounting. Now, he is a Head of Accounting Department in University of Surabaya. He has published books and articles in international journals.

Yie Ke Feliana is a Lecturer at Accounting Department University of Surabaya. She received a doctoral degree in Accounting from Airlangga University. Her research interest is financial accounting and corporate governance. Now, she is Vice Rector for Finance and Resources affairs at 
University of Surabaya. She has published books and article in several national journals and international.

This paper is a revised and expanded version of a paper entitled 'When earnings management really good news?: Indonesian evidence' presented at the 'SIBR 2016 Conference on Interdisciplinary Business and Economics Research', Bangkok, 2-3 June 2016.

\section{Introduction}

This study investigates the impact of earnings management to stock return. Previous studies about earnings management have been conducted, such as Jones (1991), Dechow et al. (1995), and Kaznik (1999) and a many more. This study develops those researches by examining the relationship between earnings management and stock return and also adds an important feature to those relationship by considering the magnitude of accruals and operating cash flow.

Relevance is one of the primary qualitative characteristics of financial reporting that usually represented by earnings response coefficient (ERC). Manager as a preparer of financial statement, uses estimation, judgments and certain level of discretion in presenting earnings figure that suit to their objectives, for example: dividend policy is one of management's motivations to present targeted earnings level (Daniel et al., 2008), meet or beat analysts' expectation to gain positive reaction from the market (Bartov et al., 2002). Other motivation to report earnings is to attain earnings threshold (Burgstahler and Dichev, 1997; DeGeorge, 1999).

Managers may use earnings management as a strategy to attract investors and potential investors. In examining the relationship between earnings management and investors' reaction, our study refers to positive accounting theory. The theory assumes that managers use accounting policy and certain level of discretion to achieve targeted earnings level. In this study, we examine management's motivation to meet targeted earnings level to make firm's stock become investors' choice. In order to realise it, managers use earnings management strategy, so that reported earnings can convince market participant about firms' value. This, in turn stimulates positive investors' reaction, such as higher stock price, higher return, lower risk and higher return for each unit risk. In summary, it can be concluded that managers use earnings management strategy to make firms' shares become investors' choice when they develop their portfolio strategy.

This study contributes to earnings management and market reaction research, because we consider the important aspect of earnings components, which are the proportion of accruals relative to operating cash flow. For firms whose accruals higher than operating cash flow, we believe that these firms use earnings management strategy using accrual component to boost their earnings. This strategy seems work, because investors fixate to earnings information and they fail to differentiate the quality of earnings components (Sloan, 1996).

Our article is presented as follow. The second section discusses hypothesis development. The third section presents research methodology, including earnings management models used in this study. The fourth section analyses the results. The last section concludes. 


\section{Hypothesis development}

Accruals and operating cash flow are two components that develop earnings. Moreover there are two accounting principles that affect earnings, there are revenue recognition and matching principles. Based on those principles, accruals are considered have a capability to mitigate timing and matching problems that is inherent in cash flow so that earnings are believed more related to future performance (Dechow, 1994).

Healy (1985) believes that managers perform earnings management through accruals. Accruals consist of discretionary and non-discretionary components. Discretionary accruals are accruals in which managers have the ability to exercise some control (Scott, 2015). In this case, it seems that using accruals stimulate another problem, since accruals give managers some discretion of using policy, judgment and estimation in reporting earnings. These conditions stimulate managers to execute earnings management through discretionary accruals since it is hard to detect (Scott, 2015). For the reason that accrual earnings management is hard to reveal, many studies use different methodology to find out how much earnings management conducted by the firms, such as Jones Model (Jones, 1991), Modified Jones Model (Dechow et al., 1995), Kaznik Model (Kaznik, 1999) and many more.

The motivation of earnings management are ranging from either opportunistically manipulating earnings or signalling private information to capital market (Dechow, 1994). Even though the intention behind earnings management is hard to determined, but vast majority of earnings management researches focus on opportunistic motivation to engage in earnings management (Cruz and Luiz, 2015). In relation to capital market reactions, earnings management is a strategy used by managers to get positive reaction from the market. Earnings is very important information, so investors are fixated by earnings information (Sloan, 1996). Market participants positively (negatively) react when top managements announce reported earnings that can (cannot) meet or beat market expectation (Burgstahler and Dichev, 1997; Bartov et al., 2002).

Given the increasing attention to earnings (as a product of accounting process), managers are stimulated to report an aggressive earnings to meet investors expectation (Chan et al., 2006). Subramanyam (1996) and Beaver and Engel (1996) also discuss the relationship between earnings management and stock return. They find positive reaction between earnings management and stock return. These results are consistent with Beneish and Vargus (2002), in which they observe that income-increasing accruals leading to positive market reaction in the short run. Supporting those ideas, we present our hypothesis as follow.

\section{$H_{1}$ : Earnings management affects stock return.}

Expanding those ideas, many studies give evidence that the ability of earnings management to predict stock return produce mixed evidence (Cruz and Luiz, 2015). It seems that managers have to consider other factors when they decide to use earnings management strategy to increase stock return, because it does not apply in all situations. Ching et al., (2006) present evidence that stock market is not fooled by the use of discretionary accruals to manage earnings. The study of Baber et al. (2006) reveal that market participants are aware of the incentives of mangers to manage reported earnings, and they adjust for the earnings management when they provided with the information to do so. Arni and Sulistiawan (2015) provide findings that income-increasing strategies generally stimulate negative effect to stock valuation, but, specifically, an income 
increasing strategy using account receivable generates positive impact to stock valuation. Their findings imply that different methods of earnings management generate different impacts to investors' behaviour.

Earnings component expresses more detail information than earnings information only. Bowen et al. (1987) break earnings into accrual and cash (or funds) flow components. They show that innovations in both components are statistically significant related to the abnormal stock returns of reporting firms (Lalepour, 2013). DuCharme and Malatesta (2004) provide evidence that normal accruals contain more information than just earnings information. Earnings quality can be expanded by reporting earnings components; which are operating cash flow and accruals. Operating cash flow results from continuing operation, they are less likely to reverse and are less subject to error and bias (Sloan, 1996). It can be concluded that earnings that are contained more operating cash flow than accruals are more persistent, and so, they have better earnings quality.

Earnings increases triggered by higher accruals indicate lower earnings persistence, which leads to lower earnings quality. Earnings quality concerns with the financial health and the capability of informed earnings and it redirects the company's exact earnings to predict future earnings (Piyawiboon, 2015). That is why earnings quality is expected to reduce mispricing. Firms that show a higher value of earnings quality measure are expected to be less mispriced on average (Pierotti and Wagenhofer, 2014). Firms with higher accruals comparing to their operating cash flow in earnings are indicated to perform earnings management. In this case, actually, operating cash flow has better capability to predict future profitability rather than accruals. Since earnings quality is low, stock price are usually mispriced and managers can use earnings management as a strategy to gain positive reaction from market participants. This argument is supported by Collins and Hribar (2000). They find out that market tends to overestimate the persistence of accrual component, so they tend to overprice accruals in the current year.

Using the idea of the magnitude of earnings components, we expect positive relation between earnings management to market performance. Our second hypothesis is presented as follow.

$\mathrm{H}_{2}$ : Earnings management positively affects stock returns for firms whose earnings contains more accruals than operating cash flow.

\section{Data and methodology}

This research analyses Indonesian Listed Company from 2011 to 2013, except for banking and financial institutions industries. Our financial data are collected from Indonesia Stock Exchange, while market data are obtained from Yahoo Finance. Indonesian stock market has lower accounting quality (Fan and Wong, 2002) comparing to several stock markets in other South-East Asian countries. By analysing the phenomenon, this study contributes to earnings management studies in developing countries. This is the contextual aspect of this study. If earnings information has low impact to investors, then earnings managements also produce low stimulation to the market.

Excess return $\left(\mathrm{EXRET}_{\mathrm{t}}\right)$ is used to represent stock return, and we use market-adjusted return. This excess return is calculated as the difference between stock return and market return. 
Earnings management is represented by discretionary accruals. Discretionary accruals (DACC) are the residual value of total accruals (TACC) minus non-discretionary accruals (NDAC).

Total Accruals (TACC) are calculated by subtracting operating cash flow from earnings (TACC $=$ EARN - OCF). These are three models that are selected to decompose total accruals into non-discretionary and discretionary accruals:

1 Jones Model (Jones, 1991)

$\mathrm{TACC}_{\mathrm{it}}=\alpha_{0}+\alpha_{1} \Delta \mathrm{REV}_{\mathrm{it}}+\alpha_{2} \mathrm{PPE}_{\mathrm{it}}+\mathrm{e}_{\mathrm{it}}$

2 Modified Jones (Dechow et al., 1995)

TACC for Modified Jones is the same with Jones Model (Jones, 1991), unless NDAC as the fitted value of TACC models are modified by:

$\mathrm{NDAC}_{\mathrm{it}}=\alpha_{0}+\alpha_{1}\left[\Delta \mathrm{REV}_{\mathrm{it}}-\Delta \mathrm{REC}_{\mathrm{it}}\right]+\alpha_{2} \mathrm{PPE}_{\mathrm{it}}+\mathrm{e}_{\mathrm{it}}$

3 Kaznik Model (Kaznik, 1999)

$\mathrm{TACC}_{\mathrm{it}}=\alpha_{0}+\alpha_{1} \Delta \mathrm{REV}_{\mathrm{it}}+\alpha_{2} \mathrm{PPE}_{\mathrm{it}}+\alpha_{3} \mathrm{OCF}_{\mathrm{it}}+\mathrm{e}_{\mathrm{it}}$

where:

$\mathrm{TACC}=$ total accruals $\left(\mathrm{EARN}_{\mathrm{t}}-\mathrm{OCF}_{\mathrm{t}}\right)$

$\Delta \mathrm{REV}=$ change in revenue from year $t-1$ to year $t\left(\mathrm{REV}_{\mathrm{t}}-\mathrm{REV}_{\mathrm{t}-1}\right)$

$\Delta \mathrm{REC}=$ change in receivable from year $t-1$ to year $t\left(\mathrm{REC}_{\mathrm{t}}-\mathrm{REC}_{\mathrm{t}-1}\right)$

$\mathrm{PPE}=$ gross property, plant, and equipment in year $t$

$\mathrm{OCF}=$ operating cash flow from statement of cash flow.

All variables are scaled by beginning total assets.

Nondiscretionary accruals (NDAC) are fitted value from above models and discretionary accruals (DAC) are defined as the residuals. $\mathrm{DEC}_{\mathrm{t}}$ is a dummy variable that represent the magnitude of accrual relative to operating cash flow. $\mathrm{DEC}_{t}$ is 1 (0) when total accrual is higher (lower) than operating cash flow. The Model is presented below:

$$
\begin{aligned}
& \text { EXRETt }=\beta_{0}+\beta_{1} \text { DEC }_{t}+\beta_{2} \text { DACC }_{t}+\beta_{3} \text { DEC }_{t}{ }^{*} \text { DACC }_{t}+\beta_{4} \text { LN_TA }_{i, t-1} \\
&+\beta_{5} \text { OCF }_{t}+\beta_{1} \text { DUM_YEAR } \\
& t
\end{aligned}
$$

where:

EXRET $_{\mathrm{t}}=$ Excess Return in year $t$.

$\mathrm{DEC}_{\mathrm{t}}=$ Dummy variable that equals one (zero) for firms with total accruals higher (lower) than operating cash flow in year $t$.

$\mathrm{DACC}_{\mathrm{t}}=($ Jones/Dechow/Kaznik): Discretionary Accruals in year $t$ using Jones/Dechow/ Kaznik model.

$\mathrm{LNTA}_{\mathrm{t}-1}=$ Natural logarithm of total assets in year $t-1$.

$\mathrm{OCF}_{\mathrm{t}}=$ Operating cash flow in year $t$

DUM_YEAR $\mathrm{t}_{\mathrm{t}}=$ dummy year. 


\section{Results and discussion}

Table 1 presents descriptive statistics. We use firms listed in Indonesia Stock Exchage and based on data availability, there are 719 firms year used in this study. Table 1 present descriptive data. Those are minimums, maximums, means and standard deviations of each variable used in our research. TACC $_{t}$ (Total Accruals in year $t$ scaled by beginning total asset) yields a range from -72.462 to 11.23 . $\mathrm{OCF}_{\mathrm{t}}$ and $\mathrm{LNTA}_{\mathrm{t}-1}$ also presented in the same way.

Discretionary accruals $\left(\mathrm{DACC}_{\mathrm{t}}\right)$ are composed using three models of earnings management. The mean value for $\mathrm{DACC}_{\mathrm{t}}$ based on Jones, Modified Jones and Kaznik Models are $0.1872,0.173$ and 0.02 respectively. $\mathrm{DEC}_{\mathrm{t}}$ is the important feature that is added to this study. We add $\mathrm{DEC}_{\mathrm{t}}$ as moderating variable to examine its ability to affect the relation between DACCt and EXRET .

Table 1 indicates that in average, EXRET produce positive return. Excess return of firms in year t presents a range from -0.941 to 10.229 with the mean is 0.227 . Those data are pooled data from 2011 to 2013.

We predict that earnings management is one of important factors that lead to positive return. In order to make firms' stocks become investors' choice, managers boost earnings through earnings management. However, in our study, by using $\mathrm{LNTA}_{\mathrm{t}-1}$ and $\mathrm{OCF}_{\mathrm{t}}$ as controlling variable, the results present that earnings management does not affect stock return. The results are not tabulated. So, H1 is not supported.

Table 1 Descriptive statistics

\begin{tabular}{|c|c|c|c|c|c|}
\hline Variable & $N$ & Minimum & Maximum & Mean & $S D$ \\
\hline $\mathrm{TACC}_{\mathrm{t}}$ & 719 & -72.462 & 11.236 & -0.136 & 3.066 \\
\hline $\mathrm{OCF}_{\mathrm{t}}$ & 719 & -3.558 & 97.992 & 0.318 & 4.544 \\
\hline $\mathrm{LNTA}_{\mathrm{t}-1}$ & 719 & 21.927 & 32.837 & 27.868 & 1.699 \\
\hline DACC $_{t}$ (Jones) & 719 & -72.192 & 173.187 & 0.187 & 7.017 \\
\hline DACC $_{t}$ (Modified Jones) & 719 & -72.219 & 173.187 & 0.173 & 7.076 \\
\hline $\mathrm{DACC}_{\mathrm{t}}($ Kaznik $)$ & 719 & -2.331 & 2.194 & 0.020 & 0.221 \\
\hline $\mathrm{DEC}_{\mathrm{t}}$ & 719 & 0 & 1 & 0.308 & 0.462 \\
\hline $\mathrm{DEC}_{\mathrm{t}} * \mathrm{DACC}_{\mathrm{t}}$ (Jones) & 719 & -3.061 & 7.614 & 0.053 & 0.448 \\
\hline $\mathrm{DEC}_{\mathrm{t}} * \mathrm{DACC}_{\mathrm{t}}$ (Modified Jones) & 719 & -0.192 & 118.828 & 0.289 & 4.669 \\
\hline $\mathrm{DEC}_{\mathrm{t}} * \mathrm{DACC}_{\mathrm{t}}($ Kaznik $)$ & 719 & -4.43 & 119.501 & 0.214 & 4.750 \\
\hline EXRET $_{t}$ & 719 & -0.941 & 10.229 & 0.227 & 0.902 \\
\hline
\end{tabular}

Notes: Variable definitions: $\mathrm{TACC}_{\mathrm{t}}$ : Total accruals in year $\mathrm{t}$ scaled by beginning total assets. $\mathrm{OCF}_{\mathrm{t}}$ Operating cash flow in year t. $\mathrm{LNTA}_{\mathrm{t}-1}$ : Natural logarithm of total

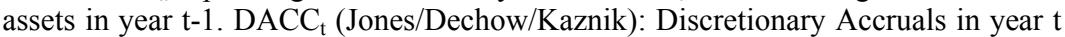
using Jones/Modified Jones/Kaznik model. DEC : Dummy variable that equals one (zero) for firms with total accrual higher (lower) than operating cash flow in year $\mathrm{t}$. EXRET $_{\mathrm{t}}$ :Stock return in year $\mathrm{t}$ after adjusted by market return in year $\mathrm{t}$.

Table 2 shows the results of our tests. Earnings management affects stock return when earnings component is dominated by accruals. Discretionary accruals generate higher return for companies that have higher accruals than its operating cash flow. The coefficient of $\mathrm{DEC}_{\mathrm{t}} * \mathrm{DACC}_{\mathrm{t}}$ is positive and statistically significant at $1 \%$. All of those 
earnings management models tend to produce similar interpretation. By using Jones Model, $\mathrm{DEC}_{\mathrm{t}} * \mathrm{DACC}_{\mathrm{t}}$ produce positive t-value (4.895). For Modified Jones and Kaznik models, t-value are 6.191 and 6.576 respectively. In this article, we present the robust results. Three models of earnings management stimulate market performance. Therefore, $\mathrm{H}_{2}$ is supported.

Table 2 Earnings management to stock return

\begin{tabular}{|c|c|c|c|c|c|c|}
\hline \multirow{2}{*}{$n=719$} & \multicolumn{2}{|c|}{ Jones Model } & \multicolumn{2}{|c|}{ Modified Jones Model } & \multicolumn{2}{|c|}{ Kaznik Model } \\
\hline & Coefficient & $t$ & Coefficient & $t$ & Coefficient & $t$ \\
\hline Constant & 1.291 & $2.307 * *$ & 1.034 & $1.853^{*}$ & 1.147 & $2.071 * *$ \\
\hline $\mathrm{DEC}_{\mathrm{t}}$ & -0.038 & -0.522 & -0.012 & -0.161 & 0.021 & 0.296 \\
\hline $\mathrm{DACC}_{\mathrm{t}}$ & -0.001 & -0.205 & -0.001 & -0.194 & -0.308 & $-1.974 * *$ \\
\hline $\mathrm{DEC}_{\mathrm{t}} * \mathrm{DACC}_{\mathrm{t}}$ & 0.370 & $4.895 * * *$ & 0.044 & $6.191 * * *$ & 0.047 & $6.576^{* * *}$ \\
\hline $\mathrm{LNTA}_{\mathrm{t}-1}$ & -0.040 & $-2.035^{* *}$ & -0.031 & $-1.596^{*}$ & -0.035 & $-1.792 * *$ \\
\hline $\mathrm{OCF}_{\mathrm{t}}$ & -0.006 & -0.739 & -0.006 & -0.737 & -0.007 & -0.906 \\
\hline Year 2011 & 0.041 & 0.497 & 0.057 & 0.701 & 0.034 & 0.419 \\
\hline Year 2012 & 0.103 & 1.243 & 0.120 & 1.468 & 0.101 & 1.246 \\
\hline $\mathrm{F}$ & \multicolumn{2}{|c|}{4.514} & \multicolumn{2}{|c|}{6.612} & \multicolumn{2}{|c|}{7.326} \\
\hline Adjusted $\mathrm{R}^{2}$ & \multicolumn{2}{|c|}{0.033} & \multicolumn{2}{|c|}{0.052} & \multicolumn{2}{|c|}{0.058} \\
\hline
\end{tabular}

Notes: Variable definitions: $\mathrm{TACC}_{\mathrm{t}}$ : Total accruals in year $\mathrm{t}$ scaled by beginning total assets. $\mathrm{OCF}_{\mathrm{t}:}$ Operating cash flow in year t. $\mathrm{LNTA}_{\mathrm{t}-1}$ : Natural logarithm of total

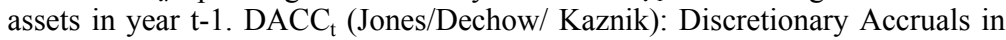
year $t$ using Jones/Modified Jones/Kaznik model. DEC $_{t}$ : Dummy variable that equals one (zero) for firms with total accrual higher (lower) than operating cash

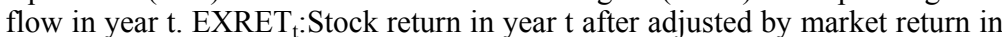
year t. $*, * *, * * *$ indicate statistical significance at the $10 \%, 5 \%$, and $1 \%$ levels, respectively.

Our results imply that the magnitude of earnings components is a moderating effect to explain the relation between earnings management and market performance. For firms with total accrual higher than operating cash flow, earnings management is an important strategy to boost stock return. Based on the basic value relevance studies, in average, good news produces positive reaction. Further analysis is conducted by splitting sample based on their profitability because the majority of the studies used profitability as a key dimension of firm performance (Sajilan et al., 2015). By assuming earnings expectation of investors is zero, we split our sample based on positive and negative net income (Table 3).

Based on Table 3, we discover that earnings management for firms with higher accruals than operating cash flow affects stock return when companies present positive earnings (Table 3 Panel A). Conversely, in negative earnings firms, stock return is not explained by $\mathrm{DACC}_{\mathrm{t}}, \mathrm{DEC}_{\mathrm{t}}$, and $\mathrm{DACC}_{\mathrm{t}} * \mathrm{DEC}_{\mathrm{t}}$ (Table 3 Panel B). These results are examined by using three models of earnings management stated above. The results are robust across the models. From the result of Table 3, it is shown that stock return cannot be explained by merely discretionary accruals or operating cash flow alone. In other words, accrual earnings management strategy to increase stock return does not apply to all condition. However, the proportion from those two earnings components has the ability to affect stock return (in this case higher proportion of accruals relative to 
operating cash flow). This result is consistent with Collins and Hribar (2000) which also find that market tends to overestimate the persistence of accrual component, so they tend to overprice accruals in the current year.

Table 3 Earnings management to excess return for profit and loss firms

\begin{tabular}{|c|c|c|c|c|c|c|}
\hline & \multicolumn{2}{|c|}{ Jones Model } & \multicolumn{2}{|c|}{ Modified Jones Model } & \multicolumn{2}{|c|}{ Kaznik Model } \\
\hline & Coefficient & $t$ & Coefficient & $t$ & Coefficient & $t$ \\
\hline \multicolumn{7}{|c|}{ Panel A: Profit Firms (Positive Net Income) } \\
\hline Constant & 1.201 & $2.046^{* *}$ & 1.071 & $1.834^{*}$ & 1.148 & $1.985^{* *}$ \\
\hline $\mathrm{DEC}_{\mathrm{it}}$ & -0.017 & -0.231 & 0.034 & 0.464 & 0.091 & 1.224 \\
\hline $\mathrm{DA}_{\mathrm{it}}$ & -0.001 & -0.223 & -0.001 & -0.205 & -0.531 & -2.465 \\
\hline $\mathrm{DEC}_{\mathrm{it}} * \mathrm{DA}_{\mathrm{it}}$ & 0.514 & $5.804 * * *$ & 0.046 & $6.579 * * *$ & 0.052 & $7.291 * * *$ \\
\hline $\mathrm{SIZE}_{\mathrm{it}-1}$ & -0.035 & $-1.717 * *$ & -0.031 & $-1.511^{*}$ & -0.033 & $-1.639 * *$ \\
\hline $\mathrm{OCF}_{\text {it }}$ & -0.007 & -0.922 & -0.007 & -0.917 & -0.009 & -1.241 \\
\hline Year2011 & 0.003 & 0.032 & 0.011 & 0.135 & -0.013 & -0.151 \\
\hline Year 2012 & 0.051 & 0.608 & 0.061 & 0.732 & 0.041 & 0.505 \\
\hline $\mathrm{F}$ & & 5.915 & & 7.327 & & 8.81 \\
\hline Adjusted $\mathrm{R}^{2}$ & & 0.53 & & 0.67 & & 0.082 \\
\hline \multicolumn{7}{|c|}{ Panel B: Loss Firms (Negative Net Income) } \\
\hline Constant & 4.01 & $1.952 *$ & 3.425 & $1.706^{*}$ & 4.036 & $1.954^{*}$ \\
\hline $\mathrm{DEC}_{\mathrm{it}}$ & -0.283 & -0.68 & -0.269 & -0.991 & -0.235 & -0.814 \\
\hline $\mathrm{DA}_{\mathrm{it}}$ & -0.001 & -0.223 & 0.05 & 0.255 & -0.146 & -0.497 \\
\hline $\mathrm{DEC}_{\mathrm{it}} * \mathrm{DA}_{\mathrm{it}}$ & 0.477 & 1.04 & 0.074 & 1.017 & 0.062 & 1.018 \\
\hline $\mathrm{SIZE}_{\mathrm{it}-1}$ & -0.147 & $-1.968 * *$ & -0.13 & $-1.767 * *$ & -0.151 & $-1.984 * *$ \\
\hline $\mathrm{OCF}_{\text {it }}$ & 0.161 & 0.375 & 0.515 & 0.829 & 0.51 & 0.712 \\
\hline Year2011 & 0.148 & 0.533 & 0.263 & 0.959 & 0.191 & 0.708 \\
\hline Year 2012 & 0.275 & 0.921 & 0.404 & 1.343 & 0.338 & 1.154 \\
\hline $\mathrm{F}$ & & 1.039 & & 1.032 & & 1.027 \\
\hline Adjusted $\mathrm{R}^{2}$ & & 0.003 & & 0.071 & & 0.002 \\
\hline
\end{tabular}

Notes: Variable definitions: TACC $_{\mathrm{t}}$ : Total accruals in year $\mathrm{t}$ scaled by beginning total assets. $\mathrm{OCF}_{\mathrm{t}}$ Operating cash flow in year t. $\mathrm{LNTA}_{\mathrm{t}-1}$ : Natural logarithm of total

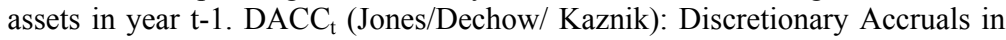
year $t$ using Jones/Modified Jones/Kaznik model. DEC $_{\mathrm{t}}$ : Dummy variable that equals one (zero) for firms with total accrual higher (lower) than operating cash flow in year t. EXRET $:$ Stock return in year $t$ after adjusted by market return in year t. $*, * *, * * *$ indicate statistical significance at the $10 \%, 5 \%$, and $1 \%$ levels, respectively.

SIZE as a controlling variable negatively affect stock return. It shows that the larger the size of the firm, the smaller excess return will be. Analysts are focus more to larger firms, so information from larger firms are relatively more observable and reflected in stock price than those from smaller firms. With the same information content, information from smaller firms will bring higher impact to the market rather than information that comes from larger firms. 
Our results show that market participants employ discretionary accruals data to evaluate market performance when (1) the gap between net income and operating cash flow is higher, and (2) firms produce profit. Bad economic condition decreases earnings relevancy (Swanson, et al., 2003); it means that accruals become less reliable (Bernard and Stober, 1989).

\section{Conclusion}

Our article has reexamined researches concerning the impact of earnings components to market performance. We present evidence that discretionary accruals are not an important factor to boost stock price. After adding an important feature, this study reports unique findings. Discretionary accruals are the important factor to improve stock return when earnings are dominated by accruals than operating cash flow. The higher accrual means that the gap between net income and operating cash flow is higher. For profit firms, accrual items that can be affected by management policies produce higher return.

Our findings give benefit to earnings management studies. Contextual aspect of the relation between earnings management and stock return is explained by our data. Using additional feature, the magnitude of accruals relative to cash flow, as an important part of our study, we present that earnings management in firms with dominant operating cash flow is not important for investors, especially when firm produce loss. Conversely, for firms that produce profit and dominant accruals relative to cash flow, this study suggests that those firms may improve shareholders' wealth by using discretionary accruals.

Some caveats apply to this article that can be an avenue for future studies. First, we only consider return in current period. For future researches, return can be extended to future return, considering there is accrual reverse in earnings management. Second, this study only considers return that is affected by earnings management strategy, in which for the next studies, it can be examined risk based return as its dependent variable. Risk based return may influence the choice of investors for their portfolio strategy. The third, using the idea of Lin et al. (2015), future researches can be developed by using R\&D expenditure, financing policy and default risk as important variables. The last, this article does not consider the adoption of IFRS as discussed in Kouki (2015). The use of IFRS implementation as an important moderating variable may produce more valuable findings.

\section{References}

Arni, F. and Sulistiawan, D. (2015) 'Can we boost stock value using income-increasing strategy? The case of Indonesia', International Journal of Applied Business and Economic Research, Vol. 13, No. 7, pp.6093-6103.

Baber, W.R., Chen, S. and Kang, S.H. (2006) 'Stock Price Reaction to Evidence of Earnings Management: Implications for Supplementary Financial Disclosure', Review of Accounting Studies, Vol 11, No. 1, pp.5-19.

Bartov, E., Givoly D. and Hayn C. (2002) 'The rewards to meeting or beating earnings expectations', Journal of Accounting and Economics, Vol. 33, pp.173-204.

Beaver, W.H. and Engel. E.E. (1996) 'Discretionary behavior with respect to allowances for loan losses and the behavior of security prices', Journal of Accounting and Economics, Vol. 22, pp.177-206. 
Beneish, M. and Vargus, M. (2002) 'Insider trading, earnings quality, and accrual mispricing', The Accounting Review, Vol. 77, No. 4, pp.755-791.

Bernard V.L. and Stober T.L. (1989) 'The nature of information in cash flows and accruals', Accounting Review, Vol 64, pp.624-652.

Bowen, R., Burgstahler, D. and L. Daley. (1987) 'The incremental content of accrual versus cash flow data', The Accounting Review, Vol. 62, pp.723-747.

Burgstahler, D. and Dichev, I. (1997) 'Earnings management to avoid earnings decreases and losses', Journal of Accounting and Economics, Vol. 24, pp.99-126.

Chan, K., Chan, L.K.C., Jegadeesh, N. and Lakonishok, J. (2006) 'Earnings quality and stock return', Journal of Business, Vol. 79, No. 3, pp.1041-1082.

Ching, K., Firth, M. and Rui, O. (2006) 'Earnings management, corporate governance and the market performance of seasoned equity offerings in Hong Kong', Journal of Contemporary Accounting \& Economics, Vol. 2, No.1, pp.73-98.

Collins, D. and Hribar, P. (2000) 'Earnings-based and accrual-based market anomalies: one effect or two?' Journal of Accounting \& Economics, Vol. 29, pp.101-123.

Cruz, D. and Luiz C. A. (2015) 'Earnings management choice: an empirical study on the impact of earnings management on stock returns', Proceedings of DLSU Research Congress, Vol. 3 , pp.1-10.

Daniel, N. D., Denis D.J. and Naveen L. (2008) 'Do firms manage earnings to meet dividend thresholds?' Journal of Accounting and Economics, Vol. 45, pp.2-26.

Dechow, P.M. (1994) 'Accounting earnings and cash flows as measures of firm performance: the role of accounting accruals', Journal of Accounting and Economics, Vol. 18, pp.3 - 42.

Dechow, P. M., Sloan R.G. and Sweeney A.P. (1995) 'Detecting earnings management', The Accounting Review, Vol. 70, pp.193-225.

DeGeorge, F., Patel, J. and Zeckhauser, R. (1999) 'Earnings management to exceed thresholds', Journal of Business, Vol. 72, No. 1, pp.1-33.

DuCharme, L.L. and Malatesta P.H. (2004) 'Earnings management and earnings surprises: stock price reactions to earnings components', pp.1-35, available at http://www.bschool.nus.edu/ Departments/FinanceNAccounting/seminars/Papers/paulmalatesta.pdf (accessed April 1, 2016).

Fan, J. P. H. and Wong T.J. (2002) 'Corporate ownership structures and the informativeness of accounting earnings in East Asia', Journal of Accounting and Economics, Vol. 33, No. 3, pp.401-425.

Healy, P. M. (1985) 'The effect of bonus schemes on accounting decisions', Journal of Accounting and economics, Vol. 7, pp.85-107.

Ialepour, M. (2013) 'The Study of Effect of earning management on capital market reactions', Life Science Journal, Vol. 10, No. 6s, pp.71-74.

Jones, J. (1991) 'Earnings management during import relief investigation', Journal of Accounting Research, Vol. 29, pp.193-228.

Kouki, A. (2015) 'Accounting valuation models under international financial reporting standards: evidence from some European listed companies', International Journal of Managerial and Financial Accounting, Vol. 7, No. 1, pp.82-101.

Kasznik, R. (1999) 'On the association between voluntary disclosure and earnings management', Journal of Accounting Research, Vol. 37, pp.57-81.

Lin, Y-M., Chen, S-L. and Chao, C-F. (2015) 'R\&D expenditure, financing policy, and default risk', International Journal of Economics and Accounting, Vol. 6, No. 1, pp.81-104.

Perotti, P. and Wagenhofer, A. (2014) 'Earnings quality measures and excess returns', Journal of Business Finance and Accounting, Vol. 41, No. 5 \& 6, pp.545-571.

Piyawiboon, C. (2015) 'Audit Quality, Effectiveness of Board Audit Committee and Earning Quality', Review of Integrative Business and Economics Research, Vol. 4, No.2, pp.366-377. 
Sajilan, S., Hadi, N.U and Tehseen S. (2015) 'Impact of Board Effectiveness and Shareholders Structure on Earnings Management in Thailand', Review of Integrative Business and Economics Research, Vol. 4, No. 2, pp.342-354.

Scott, W. R. (2015) Financial Accounting Theory. 6th edition, Toronto: Pearson Education Canada.

Sloan, R.G. (1996) 'Do stock prices fully reflect information in accruals and cash flow about future earnings?' The Accounting Review, Vol. 71, No.3, pp.289-315.

Subramanyam, K.R. (1996) 'The pricing of discretionary accruals', Journal of Accounting and Economics, Vol. 22, pp.249-281.

Swanson E.P., Rees, L. and Valdes, L.F.J. (2003) 'The Contribution of Fundamental Analysis after a Currency Devaluation', Accounting Review, Vol. 78, pp.875-902. 
International Journal of

Trade and

Global Markets 


\section{International}

\section{Journal of}

\section{Trade and}

Global Markets

Volume 10, No. 1, 2017

Publisher's website: www.inderscience.com

Email: editorial@inderscience.com

ISSN (Print) 1742-7541

ISSN (Online) 1742-755X

Copyright ( 2017 Inderscience Enterprises Ltd.

No part of this publication may be reproduced stored or transmitted in any material form or by any means (including electronic, mechanical, photocopying, recording or otherwise) without the prior written permission of the publisher, except in accordance with the provisions of the Copyright Designs and Patents Act 1988 or under the terms of a licence issued by the Copyright Licensing Agency Ltd or the Copyright Clearance Center Inc.

Published and typeset in the UK by Inderscience Enterprises Ltd 
Contents

\section{SPECIAL ISSUE: PRODUCTION, VALUE CHAIN AND MEDIA:} A CROSS-BORDER PERSPECTIVE

Guest Editor: Dr. Michael K. Fung

1 Editorial

Michael K. Fung

3 Effects of non-tariff barriers on Thai exports of key vegetables to ASEAN countries

Jirawat Jaroensathapornkul

13 Financial management using moderate capitalism for dairy cow farms in Maha Sarakham Province, Thailand

Phanita Soonthornchai

19 Sustainable entrepreneurship in industrial ecology: the cheese case in Mexico

Manuel Alexis Vázquez Zacarias, Eduardo Aguiñaga and

Elias Alvarado Lagunas

28 The relationship between creativity, entrepreneurial attitude and entrepreneurial intention (case study on the students of State Polytechnic Malang)

Anik Kusmintarti, Andi Asdani and Nur Indah Riwajanti

37 The effect of corporate strategy on earnings management Ali Muktiyanto

47 When is earnings management really good news? Evidences from Indonesia Felizia Arni Rudiawarni, Dedhy Sulistiawan and Yie Ke Feliana

58 The determinants of risk disclosure in the Indonesian non-listed banks Dwi Nita Aryani and Khaled Hussainey

67 Internet banking service quality in South Africa: a qualitative analysis of consumer perceptions

Ephrem H. Redda, Jhalukpreya Surujlal and Verona Leendertz

75 Causality nexus between trade, political instability, FDI and economic growth: Nigeria experience

Nor'Aznin Abu Bakar and Luqman Afolabi 
83 Machiavellianism, tax knowledge, and ethical perceptions of tax avoidsurvey of undergraduate students in West Java, Indon esia Arie Pratama

91 Analysis of economy aspects in the policy on establishing housing and settlement in West Java, Indonesia Suryanto and Budiman Rusli Ownership structure and operational efficiency in emerging market: case of Korea

Jayoun Won and Sang-Lyul Ryu

108 The unemployment impact of immigrant workers in Thailand Nisit Panthamit

115 Household savings of Slovakia: effects of banks, dependency ratio, transitory income and unemployment Renáta Pitoňáková

Forecasting methods for safeguarding ASEAN-5 stock exchanges duri extreme volatility Chukiat Chaiboonsri and Prasert Chaitip 


\section{International Journal of Trade and Global Markets (IJTGM)}

Editor: Prof. Bruno S. Sergi

University of Messina, Department of Economics, Via dei Verdi, 75, 98122 Messina, Italy

Email: bsergi@unime.it

Associate Editor: Professor Patrick O'Sullivan

Professor of Business Ethics; Head of Department Grenoble Ecole de Management

Department of People Organisations and Society

12 Rue Pierre Sémard, 38003 Grenoble, France

Email: patrick.osullivan@grenoble-em.com

Regional Editor Africa: Professor Rachel Barker

University of South Africa, Department of Communication Sciences

7-91 Theo van Wijk Building, P.O. Box 392, UNISA, Pretoria 0003, South Africa

Email: barker@unisa.ac.za

Regional Editor Asia: Professor Michael K. Fung

School of Accounting and Finance, Hong Kong Polytechnic University

Hung Hom, Kowloon, Hong Kong

Email: afmikef@polyu.edu.hk

Regional Editor Europe: Professor Roman Matousek

Kent Business School, University of Kent, Canterbury, Kent, CT2 7PE, UK

Email: R.Matousek@kent.ac.uk

Regional Editor USA: Professor Dr. Abel Adekola

University of Wisconsin, Stout, 144 Jarvis Hall, Menomonie, WI 54751, USA

Email: adekolaa@uwstout.edu

\section{Members of the Editorial Board}

Dr. Abdelgader M.A. Abdalla

University of Khartoum

School of Management Studies

PO Box 321, Sudan

Email: kadersab35@yahoo.com

Dr. William T. Bagatelas

University of New York in Prague

Legerova 72, 120 00, Praha, Czech Republic

Email: bbagatelas@gmail.com

Dr. Tomasz Bernat, Acting Chair

University of Szczecin

Microeconomics Department

Mickiewicza Str. 64, room 430

71101 Szczecin, Poland

Email: bernatom@o2.pl

\section{Dr. Vito Bobek}

University of Applied Sciences

FH Joanneum, Eggenberger Allee 11

8020 Graz, Austria

Email: vito.bobek@fh-joanneum.at

Professor Tatiana Chetvernina

Director of the Institute for Social

Development Studies, State University

Higher

School of Economics, Myasnitskaya str.

20-407, 101000, Moscow, Russia

Email: tchetvernina@hse.ru
Professor Musa Essayyad

Dean and Professor of Finance

College of Business

McNeese State University

Lake Charles, LA 70609, USA

Professor Mark Esposito

Harvard University Extension School Lab-Centre for Competitiveness and

Grenoble Ecole de Management

12 Rue Pierre Sémard

38003 Grenoble, France

Email:mark@mark-esposito.com

Professor Fernando J. Fuentes García Vice-Dean, University of Córdoba

Faculty of Law, Economy and

Business Administration

C Puerta Nueva s/n 14071 Córdoba, Spain

Email: Fernando.fuentes@uco.es

\section{Professor Dainora Grundey}

Vilnius University

Kaunas Faculty of Humanities

Muitines g. 8, Kaunas,

LT-44280, Lithuania

Email: grundey@vukhf.lt 


\section{Professor $\mathrm{Yu}$ Hsing}

Southeastern Louisiana University

Department of Business Administration

College of Business,

Room 60, R. Norval Garrett Hall, SLU

10813, Hammond

Louisiana 70402, USA

Email: yhsing@selu.edu

Professor Tatiana M. Isachenko

Moscow State Institute of International

Relations (MGIMO)

Department of International Economic

Relations, 76, Vernadsky Av.

119454 Moscow, Russian Federation

Email: isachenko@mgimo.ru

\section{Dr. Craig Julian}

Southern Cross University

Southern Cross Business School

Gold Coast Campus, Locked Mail Bag 4

Coolangatta Qld 4225, Australia

Email: craig.julian@scu.edu.au

Assoc. Prof. Mansoor Maitah

Faculty of Economics and Management,

Czech University of Life Sciences Prague

16521 Praha 6 Suchdol

Czech Republic

Email:maitah@pef.czu.cz

Professor Dr. Bogdan Mroz

Warsaw School of Economics Department of Living Standards and

Consumption, al. Niepodleglosci 164 Office 1016, 02-554 Warsaw, Poland

Email: bogdan.mroz@sgh.waw.pl

Professor Shahdad Naghshpour

The University of Southern Mississippi

730 East Beach Boulevard

Long Beach, MS 39560, USA

Email: s.naghshpour@usm.edu

Professor Dr. Fon Sim Ong

Professor of Marketing

Nottingham University Business School

The University of Nottingham

Malaysia Campus

43500, Selangor, Malaysia

Email: fonsim.ongfonsim@gmail.com

Dr. James E. Payne

Dean, J. Whitney Bunting

College of Business

Georgia College \& State University

231 West Hancock Street

CBX 010, Milledgeville, GA 31060, USA

Email: james.payne@gcsu.edu
Professor Carlo Bellavite Pellegrini

Catholic University of the Sacred Hea Milan, Department of Economic and B Management Sciences, via Necchi 5, 21 Milan, Italy

Email: carlo.bellavite@unicatt.it

\section{Professor Irina N. Platonova}

Moscow State Institute of Internationa Relations, MGIMO - (University) of M of Foreign Affairs of Russian Federatis Vernadsky Prospect

76, 119454, Moscow, Russia Email: platonova@mgimo.ru

\section{Qerim Qerimi}

Max Planck Institute for Comparative P Law and International Law Im Neuenheimer Feld 535 D-69120 Heidelberg, Germany Email: qqerimi@yahoo.com

\section{Professor David McHardy Reid} Seattle University

Albers School of Business \& Economis 901 12th Avenue, P.O. Box 222000 Seattle, WA 98122-1090, USA Email: reidd@seattleu.edu

Dr. Werner Sengen berger

7 Les Collines de Pitegny 385 Chemin de l'Ovellas F-01170 Gex, France Email: sengenberger.w@wanadoo.fr

Professor Sandra Sánchez Cañizare University of Córdoba Department of Statistics and Business Administration, Faculty of Law, Econ Business Administration,

C Puerta Nueva s/n 14071 Córdoba, S. Email: sandra.sanchez@uco.es

\section{Dr. George O. Tasie}

Associate Professor of Management Gulf University for Science and Tec College of Business Administration PO Box 7207, Hawally 32093, Kuwar Email: Tasie.G@gust.edu.kw

Professor Park Thaichon

S. P. Jain School of Global Managemer 5 Figtree Drive

Sydney Olympic Park Sydney, NSW, 2127, Australia Email: park.thaichon@spjain.org 
Members of the Editorial Board (continued)

Professor Terence Tse

ESCP Europe

27 Finchley Road, Hampstead,

London NW3 7BG, UK

Email: ttse@escpeurope.eu

Professor Manuela Tvaronaviciene

Vilnius Gediminas Technical University

Business Management Faculty

Department of Enterprise Economics and

Business Management

Sauletekio 11, 10223 Vilnius, Lithuania

Email:manuela@post.omnitel.net manuela@vv.vtu.It
Professor Dr. Ljiljana Viducic

University of Split, Faculty of Economics

Matice hrvatske 31, 21000 Split, Croatia

Email: Ividucic@efst.hr

Dr. Evelyn Wamboye

Pennsylvania State University

Business Department

102K DEF Building

College Place, DuBois, PA, 15801, USA

Email: efw10@psu.edu 